\title{
The GIS-ENDDB algorithms and methods for geoinformation-expert data analysis*
}

\author{
A. V. Mikheeva ${ }^{1}$ and I. I. Kalinnikov ${ }^{2}$ \\ anna@omzg.sscc.ru \\ ${ }^{1}$ Institute of Computational Mathematics and Mathematical Geophysics SB RAS, 6 Acad. \\ Lavrentjeva pr., Novosibirsk, Russia \\ ${ }^{2}$ Schmidt Institute of Physics of the Earth of RAS, 10/1 Bolshaya Gruzinskaya Str., Moscow, Russia \\ The software of the geographical information system for studying the Earth's natural disasters \\ (GIS-ENDDB) is focused on the research into cause-and-effect relations of catastrophic events \\ in our planet's history. It contains data on the Earth's seismic activity, anomalies of heat \\ flows (HF), gravitational field and tomography layers, detailed geographical relief, as well as \\ data on cosmogenic structures distribution. To develop methods for analyzing these data, it \\ has been added into the subsystems of information and mathematical software updates such \\ as: the algorithm for building seismicity lineaments in terms of the Great circles (GC) of the \\ Earth; the algorithms for constructing the contours of a maximum earthquake magnitudes and \\ of the averaging earthquake mechanisms; the functions of geophysical fields visualization and \\ the cross-section visualization of different seismicity characteristics; and tomography data. All \\ these updates help to extend the capabilities of classical methods for geotectonic studies by \\ a complex scientific-experimental approach allowing one to reveal tectonically active faults, \\ to study the spatial relationship of seismicity and cosmogenic paleostructures (related to the \\ historical past of the Earth), and, eventually, to interpret the data in terms of constructing \\ seismic-geodynamic models of the lithosphere.
}

Keywords: impact structures and seismicity catalogs; morphostructural elements; geophysical anomalies; expert-geoinformation approach

DOI: $10.21469 / 22233792.3 .1 .03$

\section{Introduction}

When solving the geotectonic and geomorphological problems, the researcher cannot take into account all the factors affecting the dynamics of real geophysical manifestations; so, interpretating the results, he/she often runs into an ambiguous and undefined choice. Such state of affairs is an unavoidable consequence of geophysical processes' multidimensionality. However, the more powerful the GIS is, the better the researcher's needs are realized toward gradual, step-by-step choice of the most reliable variant among many possible variants. Such a system is the program GIS-ENDDB $[1,2]$ that allows nonprogrammer users, communicating with a computer, to formulate and to solve their own intellectual tasks. The methodological basis of the research is the methods for physical-mathematical analysis, the GIS-methods, and the expert-geoinformation approaches $[3,4]$ to the data interpretation for the geodynamic problems solution (Fig. 1).

The data representation structures, the analysis methods, and the visualization algorithms are described in detail in [5]. Briefly, there are used algorithms for detecting linear and annular structures and subsequent analysis of their seismogeodynamic regime. The algorithms of calculation and building the zonal maps of spatial distributions of different seismic parameters (b, $A, E_{O}$, and $K_{\mathrm{AVG}}$ ) [5] (see Fig. 1) include the visualization of its spatial distributions (uses the two-dimensional Bessel linear interpolation) on uniform intervals of time, the detection

\footnotetext{
*The research was supported by the Russian Foundation for Basic Research (grant 17-05-01234).
} 


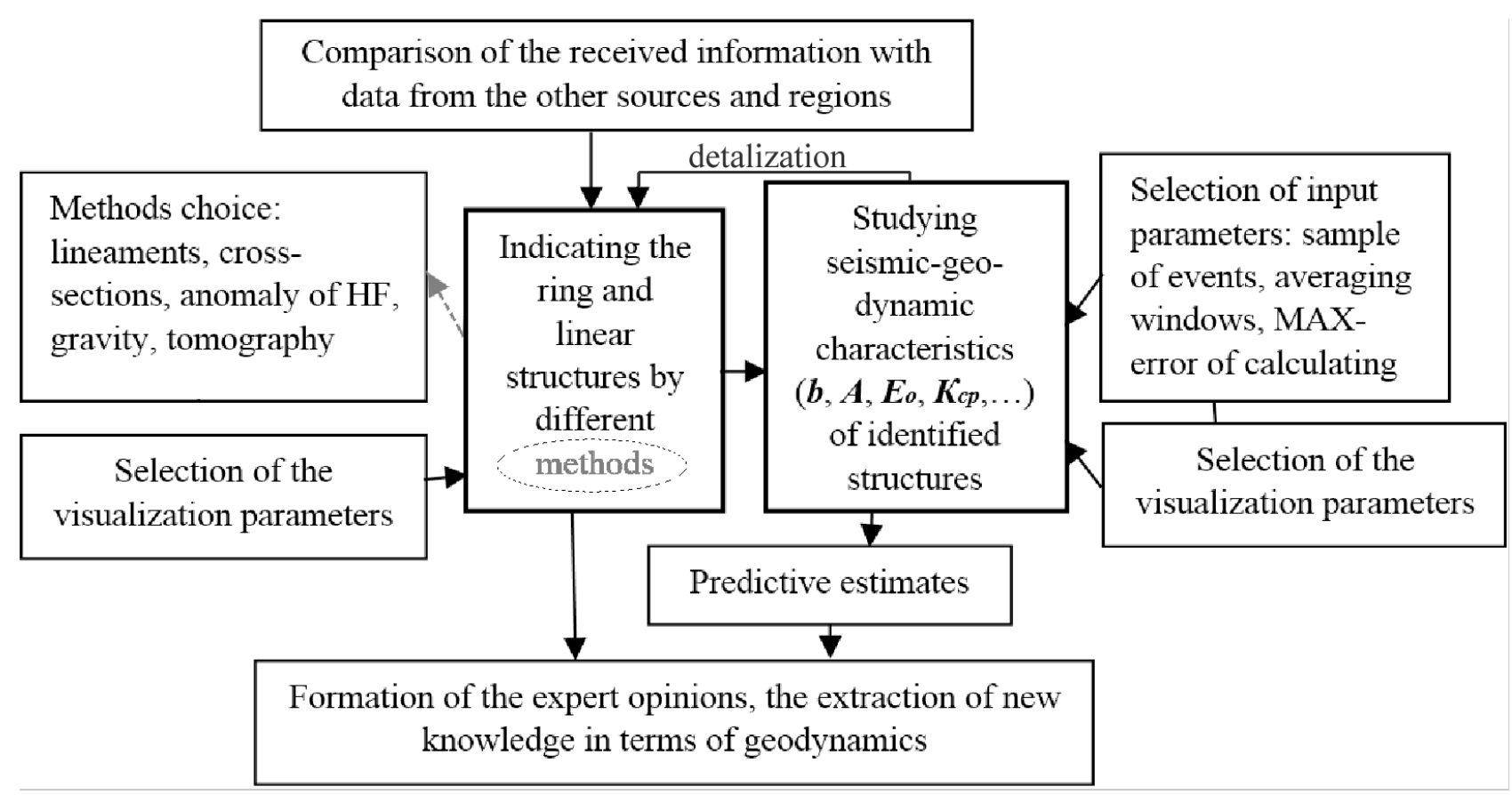

Figure 1 An example of the scenario using the GIS-ENDDB tools for "expert-geoinformation" analysis of natural disaster data

of spatial-temporal anomalies, and estimation of their statistical significance. The reliability of parameters' determination is controlled: (1) by the root-mean-square deviation $\sigma$ of the repeatability curve points with respect to the approximating straight line [5]; (2) by the representativeness of the sample [5] (an error $\varepsilon \sim N$ ); and (3) taking into account errors in the definitions of catalog parameters: $\delta \varphi, \delta \lambda$, and $\delta t_{0}$. The method (3) is realized by an iteratively adjustable grid of calculations until the anomalies stability is reached. Method (2) is operated by the constructing maps of the events $N$ (number in the computation cell). Then, the identified anomalies are verified with other geophysical data. For geophysical fields visualization, the GIS-ENDDB cartographical subsystem uses shaded-relief raster images for creating digital geographic maps. The three-dimensional (3D) effect is provided by successive triangulations and by calculating the brightness of triangles.

By mapping these obtained seismic parameters distributions and comparing them with the anomalies of geophysical fields: gravitational, HF, and tomography [6], using our shaded relief model and their digital models, we can verify the linear and ring geodynamic patterns associated with Plate, Plume, and Impact tectonics and check their validity in different territories.

At present, there are no programs of the GIS-ENDDB level for geodynamics comprehensive study, but a wide range of software products and algorithms for complex seismic process analysis or for specific geodynamic characteristics study is known [5]. However, most of them are limited territorially or aimed at solving a narrow range of tasks [3]. Their main drawback is excessive automation at the decision-making stage. The GIS-ENDDB system is a system of expert assessments avoiding unnecessary automation and mathematization. Its advantage is the synchronous analysis of seismic, volcanic, and impact structure distributions along with different geophysical fields.

In this paper, the algorithms for detecting linear and annular structures, i. e., the first of two central functional blocks (see Fig. 1) for studying the regional geotectonic, are considered in more detail. 


\section{Geoinformation technology used in the ENDDB system}

The ENDDB object base consists of a seismic, volcanic, and impact natural disasters data, in particular, 63 catalogs of historical and modern earthquakes. The comparative analysis of completeness of various seismological catalogs intersecting on the maps carried out with the help of the GIS-ENDDB (using histograms of the average events number per time unit and the dependence curve of the magnitudes registered in the events catalog on time) conditionally enables one to zone a geographical map into regions with indication to a preferable catalog.

The GIS-ENDDB methods for physical-mathematical analysis are the main principles of the probability theory and mathematical statistics, the physical laws of environment continuity destruction, other achievements of the Russian and foreign authors in the research subject area (see, for example, [3]). Methods for graphical and spatial-temporal analyses of the main seismic and geodynamic processes characteristics inherited from the analysis subsystem of the GIS-EEDB (the Expert Earthquake Database) [7, 8] and supplemented by the functions of calculating their distribution in the cross sections along the multidirectional profiles indicated by user, allow obtaining the multidimensional data visualization. In addition, in the GIS-ENDDB environment, the algorithms for detecting the events groups of the spatial and spatial-temporal range: aftershocks, swarms, scattering ellipses, clusters, chains, seismolineaments (Fig. 2a) as well as dive slabs and deep channels are being developed [5, 7, 8]. Comparison of different algorithms effectiveness for group detecting can be carried out by estimating the statistical properties of the events swarms. It shows the more effective algorithm in each case.

By revealing clusters, swarms, and seismolineaments, the structure of seismicity, which then can be compared to geological structures, has been established. In particular, the method of structural lineament construction is based on the underlying physical principles of environment destruction: the causal conditionality, which is expressed in a chronological sequence of spatially related events; the requirement of a potential energy minimum of the discontinuity surface; and the statistical reliability provided by events of a seismolineament. Despite the fact that the geophysical environment is not isotropic and has a block-layered structure and the stress field

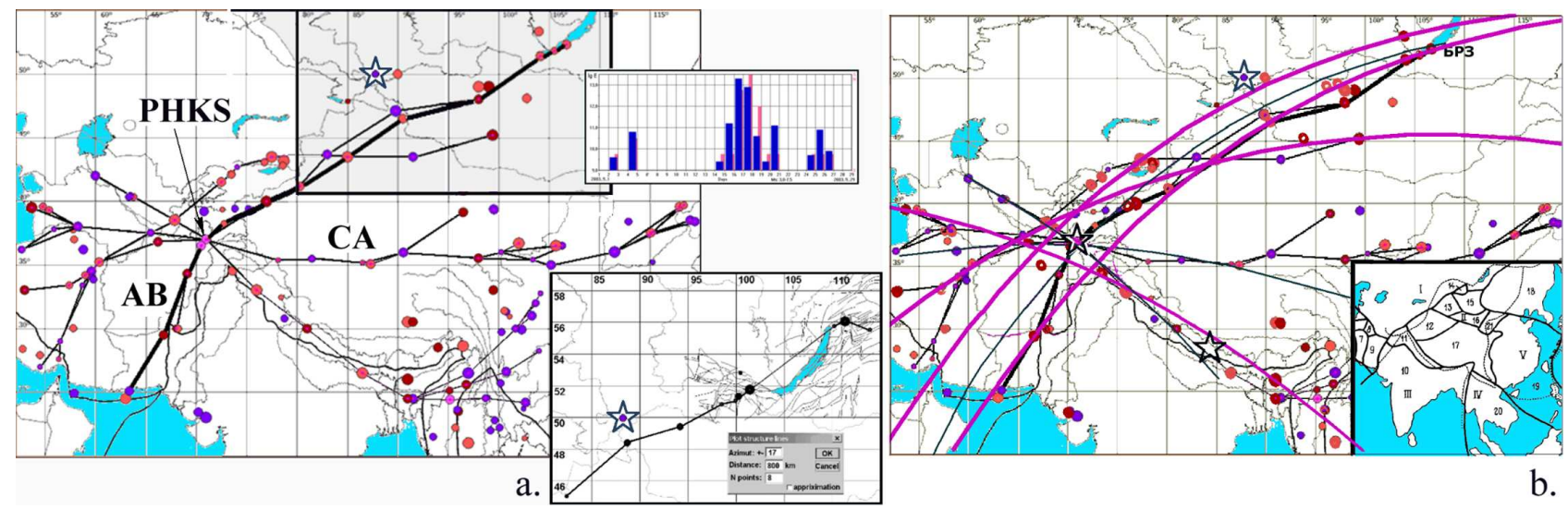

Figure 2 The seismic lineaments system of the Arabian Plate - the BRZ - the Himalayas (Significant Catalog; (-250)-2008 years): (a) the PR-lineaments [8] with the bright AB lineament. In the inserted pictures, the earthquake cluster of September 14-20, 2003, $M_{s} \geqslant 3$ in the last month (September) before the Chui earthquake (27.09.2003, $\left.M_{w}=7.3\right)$ : at the top - on the timeline with a step of 1 day; at the bottom - on the map (the Chui event marked with an asterisk); and (b) the GC-lineaments: the lilac arc lines are seismolineaments of $M_{s} \geqslant 7.2 ; 15 \leqslant H \leqslant 80 \mathrm{~km}$. In the inserted pictures, the scheme of plates and microplates borders according to different authors [9] 
is nonuniform, the final implementation of the physical laws actions at the global (interregional) scale should tend toward the lineaments, i. e., to geometrical shapes, providing a surface energy minimum. These shapes are "planes," "cylinders," "spheroids" as well as in plan: "rings," "lines," and "dendrite-like crack" [10]. In particular, by now, within the GIS-ENDDB, we have developed the algorithm for detecting linear structures involving the validity of the fundamental physics laws in the global geodynamic processes: the above-mentioned least action principle, which requires the destruction of a uniform environment on segments of the GC if a discontinuity overcomes the Moho layer (see Fig. 2). In this case, the seismolineaments reflect the results of geological processes, only partially enclosed by the instrumental seismic data (available only for the last century) and, in our opinion, allow us to reconstruct the long-term geological processes within a single mechanism of structures formation, not yet accepted in geology [11].

The term "seismolineament" is defined by the authors as linear, arc-shaped, and annular structures detected by the distribution in lateral of given rank seismicity magnitudes, which are directly or indirectly related to the active faults of the corresponding rank and reflecting the current stress-strain state of the upper layers of the lithosphere.

Let us list the main concepts of the new algorithm (conditionally called GC) having only three defined parameters: the number of points in the chain $n_{\min }$, the maximum distance between the reference events $L$ (in $\mathrm{km}$ ) and $d$ - the divisor of $L$ for calculating the bandwidth of the GC. The first parameter provides statistical representation of building and the second, the geometrical one, takes into account the effect of the Earth's crust sphericity at distances of $L$, which, at least, should twice exceed the focal zone size of the strongest earthquakes and must be essentially greater than the thickness of the Earth's crust.

1. Suppose that $N_{\max }$ is the total number of selected events (for example, only the crust ones) from the ancient times with $\left(M_{\max }-2\right) \leqslant M_{s} \leqslant M_{\max }$ and a predetermined depth, as well as with a random spatial distribution, and a temporal distribution variance $\sqrt{N_{\max }}$.

2. Calculate $R(1, i)$, i. e., the distance between the chronologically first and all the subsequent events.

3. Repeat Step 2 for all the subsequent events until the number of columns is $N=4 \sqrt{N_{\max }}$. As one may expect, this sample ensures the presence of at least one strong event with its fault.

4. Select all the events (from each of $N$ columns) where every two chronologically successive ones are located no closer than $L / 2$.

5. Between each two chronologically close events satisfying the condition posed on the distance $L / 2 \leqslant R(j, i) \leqslant L$, let us assume the presence of a stress field, which may generate an elongated tectonic fault with a minimum surface energy, i. e., throughout the GC. Therefore, through each pair of such events and the Earth's center, one may build a plane dissecting the lithosphere by the GC.

6. Compute a distance to all the events in the catalog for all the planes constructed, selecting the GC planes with a sufficient number $\left(n \geqslant n_{\min }\right)$ of closely located events (with a distance from the plane: $\Delta h \leqslant L / d)$.

The algorithm implies the expert's skill in setting the events selection and the control parameters $\Delta h$ and $L$ taking into account many complicated factors: different reliability of data on modern and ancient earthquakes; uncertainty of the criteria for throwing away the clearly false candidates for seismolineaments; etc. The advantage of the algorithm is its speed relative to the previous version of seismolineaments constructing (by pattern recognition (PR) [8], see Fig. 2a). The same structures (with some excess) are detected, in this case, in a few seconds 


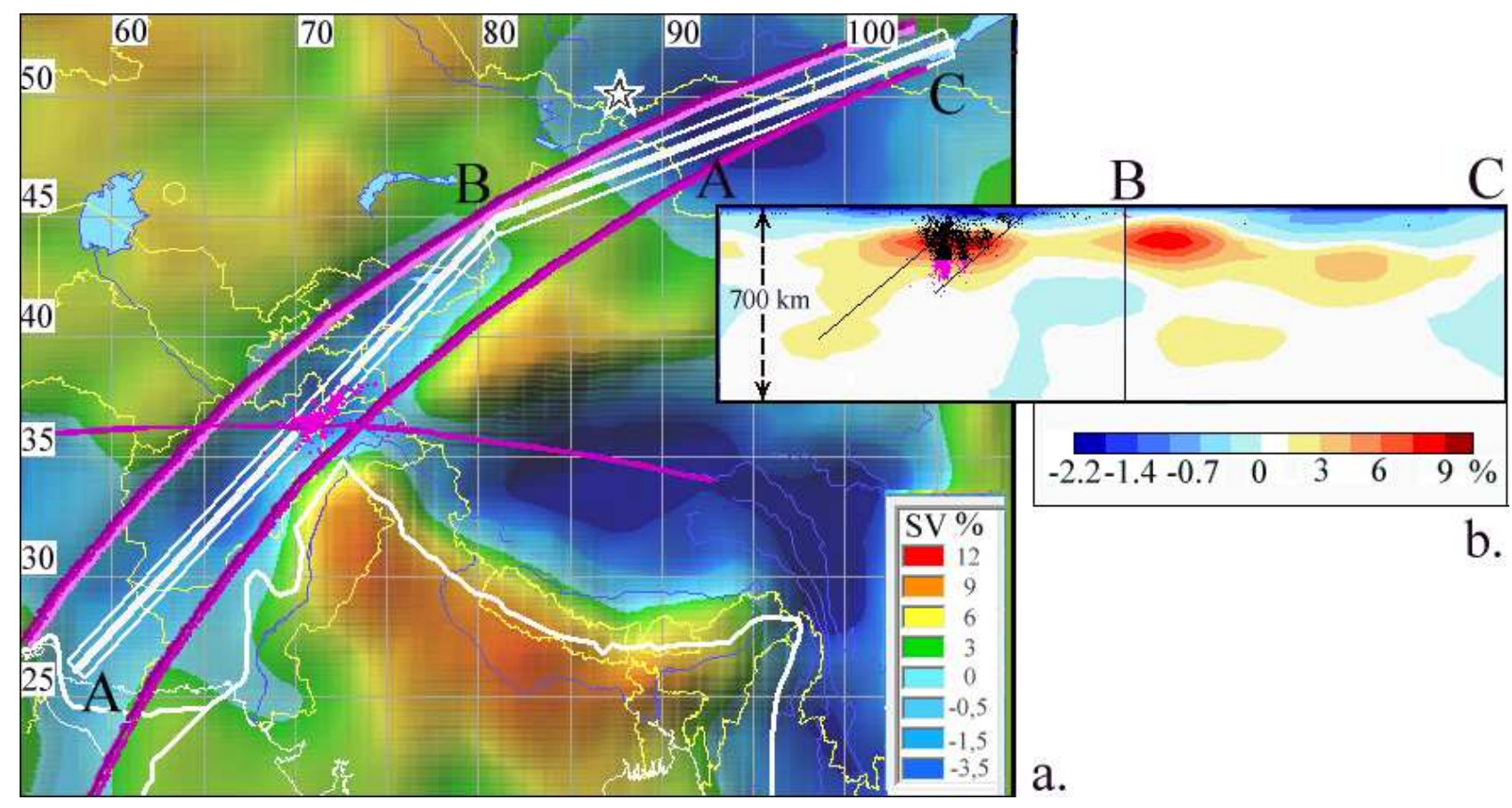

Figure 3 The association of seismicity with the tomographic anomalies: $(a)$ the seismic GC-lineaments (purple) of the CA region, the PHKS zone earthquakes swarm of $H \geqslant 200$ (lilac) and the profile $A B C$ (white) on the background map of the tomographic anomalies (perturbation from the reference $S_{V^{-}}$ velocity [6]) in layer of $H=75 \mathrm{~km}$; and (b) the tomography cross section along the profile $A B C$ and the full seismicity swarm. The asterisk in $(a)$ marks the epicenter of the Chui earthquake, white curve - the interplate border

while earlier, it took several tens of minutes. In the manual sorting mode, this enables to carry out the optimizational search for significant GC, for example, by the criterion of a minimum relationship $h=L / n_{\min }$ or the width of a fault zone $\Delta h$ definition. In these both cases, the choice should correspond to the real geophysical environment. Figure $2 b$ presents the GClineaments corresponding to local minima of $h$. They are associated with the known boundaries of tectonic plates, i. e., meet the criterion of fault deepness.

Currently, the GC-algorithm is being tested on real seismicity material in Central Asia, the Pacific subduction zone, and other seismic-prone regions. For example, with the seismolineament construction algorithms, the central-oriented regional seismolineaments system of Central Asia has been detected [12] on the temporal interval of 2250 years with the most extended "Central-Asian" (CA) and the "African-Baikal" (AB) seismolineaments (see Fig. 2) corresponding, respectively, to the Alpine-Himalayan seismic belt and the Intra-Asian mountain belt. Both these superlineaments are confirmed by the linear negative tomography anomalies up to $80 \mathrm{~km}$ depth (Fig. 3a) and by the linear "compressing" anomalies (of the same trend) of averaging mechanisms field (see details below). The representation of the $A B$-lineament in its northern part (between Balkhash and Baikal lakes) is confirmed by the Chui cluster of the same trend but of a shorter-term (1 week) and of a weaker energy (found in the events with $\left.M_{s} \geqslant 3[1,2]\right)$, which was a short-term precursor of the major Chui earthquake in the Altai region (the inserted pictures in Fig. $2 a$ ). The $A B$-lineament is confirmed, also, by the statistical analysis: by the linear shape of the isolines of the total seismic energy released per unit area or of the summary earthquakes number [13] as well as by one of the recently developed methods: $M_{\max }$-contour configuration (maximum earthquake magnitudes) (Fig. 4) where the seismolin- 


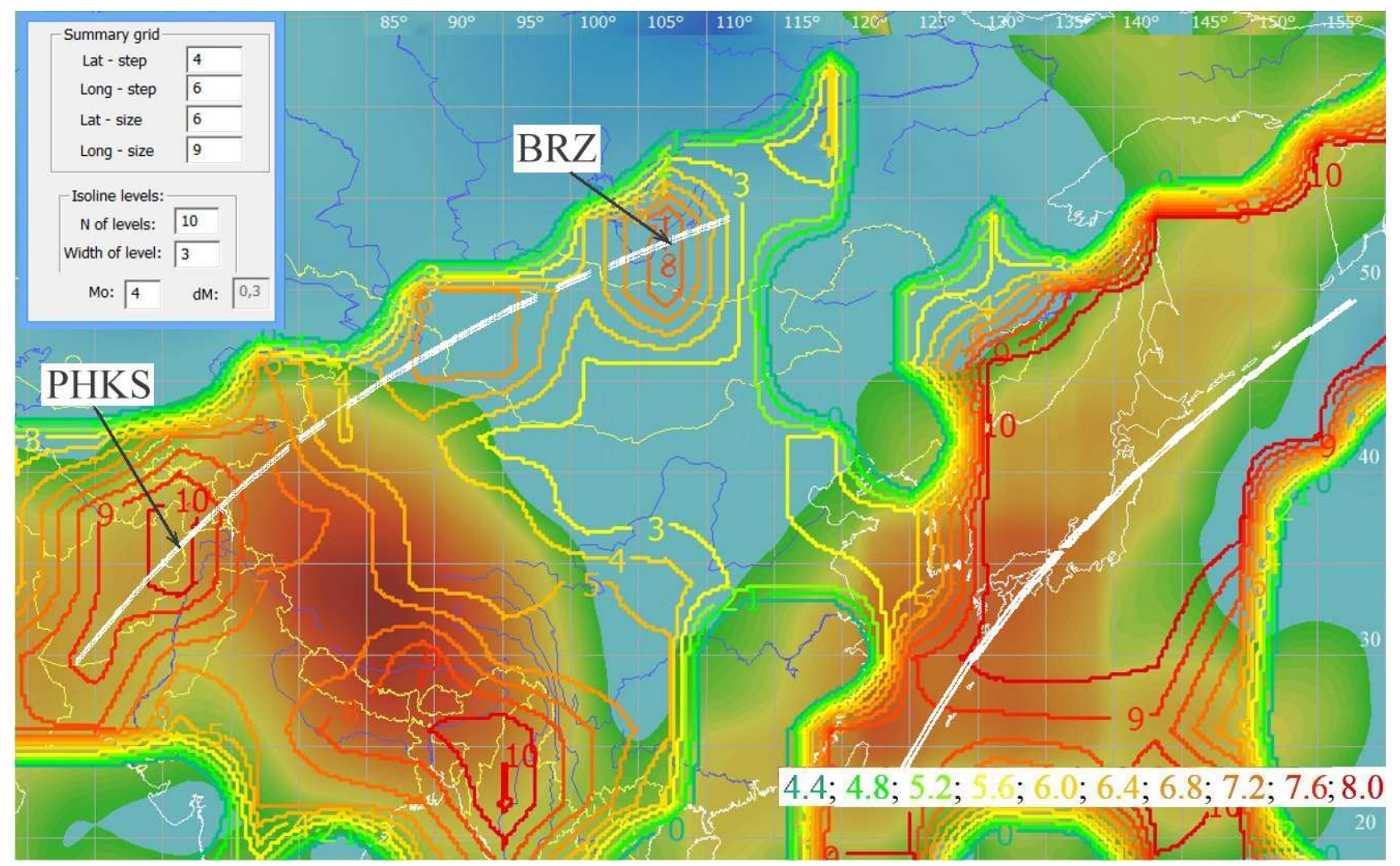

Figure 4 The $M_{\max }$-isolines according to the COMPLEX [2] catalog, $4 \leqslant M_{s} \leqslant 8$ on the regional component map background of the HF obtained by the same averaging. Parameters of building $M_{\max ^{-}}$ contours: $H \leqslant 34 \mathrm{~km}$; the averaging cell $6^{\circ} \times 9^{\circ}$; step $4^{\circ} \times 6^{\circ}$ (contour lines $1 ; 2 ; \ldots ; 10$ correspond to the magnitude of $\left.M_{s}=4.0-4.4 ; \ldots ; 7.6-8.0\right)$

eament structure is even more extended to the north-east (up to the Viluy-Lena watershed). From this corner point, the linear structure extends over the Baikal rift zone (BRZ) to the south-west with value 8 of maximum intensity (i. e., $M_{\max } \leqslant 7.2$ ) in the BRZ and 10 (i.e., $M_{\max } \leqslant 8$ ) in the Pamir Hindu Kush area (see Fig. 4). One can also see that the $M_{\max }$-contour covering the "Taiwan-Kuril" seismolineament (see Fig. 4, on the right) is constructed according to the Japanese catalog JMA with the parameters: $\left(L, n_{\text {min }}\right)=(2,550 \mathrm{~km}, 29) ; 7 \leqslant M_{s} \leqslant 9$; $15 \leqslant H \leqslant 40 \mathrm{~km}$; years 1923-2013, whose influence zone includes the Great East Japan Earthquake $\left(M_{w}=9.0\right)$ and the recent strongest events of the region $\left(2016.04 .14,16: 25 ; M_{s}=7\right.$; $\left.32.78^{\circ} \mathrm{N}, 130.73^{\circ} \mathrm{E}\right)$.

Mapping the seismolineaments on the background of the GIS-ENDDB maps in terms of digital gravimetric models of Remote Sensing Data (especially, of its regional features) or the digital tomography model [6] allows one to discover its association with a deep (mantle) origin inhomogeneities of a geophysical field. The methods for tectonic structures diagnosis on geophysical maps by the GIS-ENDDB facilities are in visual selection of an optimum color palette and foreshortening of an image (or illumination ray parameters and a pseudo-3D model shadow depth) as well as in selecting optimal averaging values (if smoothing is necessary). These procedures (as well as the procedure of cross-sections building, see Fig. 4b) allow one to obtain the most informative 3D images of a relief, gravity, HF, and tomography and to gather data for establishing standard morphostructural elements of the channel-shaped (in the vertical cross section), ring and linear (in plan) structures of endogenous or cosmic origin (see Figs. 4 and 5). 

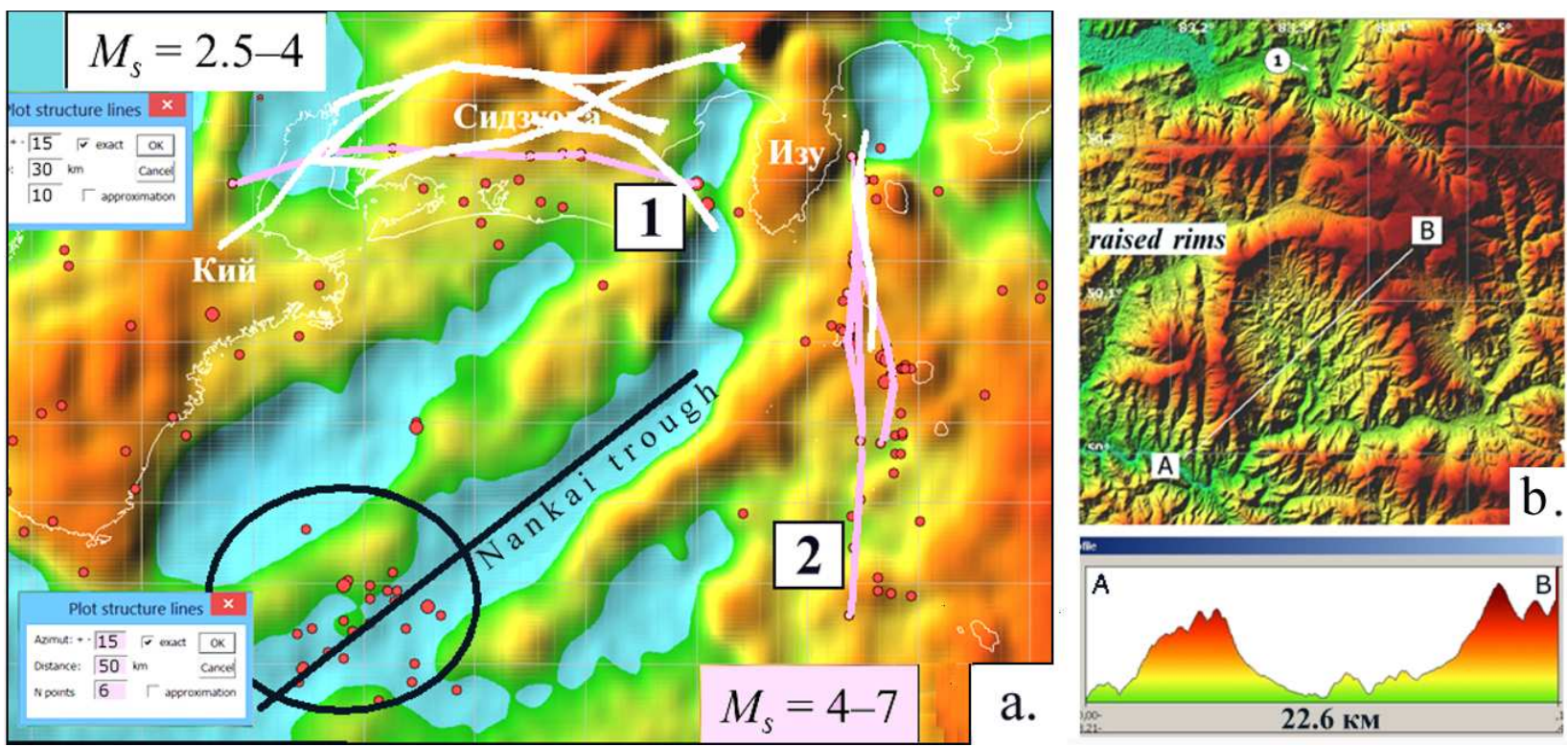

Figure 5 Examples of ring and linear structures identified by various GIS-ENDDB methods: $(a)$ by the digital model of gravity anomalies and arcuate seismicity lineament (JMA catalog, $H \leqslant 50 \mathrm{~km}$ ) around the Nankai trough area, an oval marks the area of long-term concentration of seismicity, and $(b)$ by the detailed topography ASTER GDEM (in the map and cross section) for the crater "Chasha" [14]

All expert methods for structures identification depending on the different information are the following [4]:

1. The above-mentioned seismolineaments construction in term of the linear and ring seismicity distribution in the plan $[2,12]$ (see Figs. 2 and $5 a$ ).

2. The seismicity distribution in cross sections (on the background of tomography data or without background) to detect tectonically active deep areas and "seismic nails" [15] (see Fig. $3 b)$.

3. The gravity or tomography anomalies configuration $[1,2]$ (see Fig. $3 a$ ).

4. The HF anomalies configuration and intensity [2] (see Fig. 4).

5. The configuration of anomaly distribution zones of seismic regime characteristics $[2,4,13]$ (for examlpe, of $M_{\max }$, see Fig. 4).

6. The detailed relief structures in the plan and in the cross section [2] (see Fig. 5b).

7. The averaging earthquake mechanisms anomalies configuration.

8. The geological-tectonic data from other sources (for example, the active faults and blocks, tectonomagnetic observations, etc.).

All the above-said is necessary for the formulation and solution of many geotectonic and geomorphological tasks, covering the geophysical processes multiple components. Such tasks are, for example, as follows:

- to reveal patterns of seismogenic structures (according to seismological catalogs $[1,2,7,8]$ );

- to confirm the new diagnostic morphological features [1,2] of astroblems (according to the "Earth's impact structures Catalog" [14]); and

- to detect and confirm potential structures of complex multistage genesis such as impactmagmatic, impact-tectonic (according to the entire range of data [2]: gravimetrical, thermal, seismic, cosmogenic, etc.). 
For example, let us consider the GIS-ENDDB methods when analyzing the entire range of the above-said center's data of the central-oriented seismolineament system (see Fig. 2a). This center is a special geodynamic region called the Pamir Hindu Kush seismofocal (PHKS) zone.

\section{The application results of the GIS-ENDDB methods}

First, at the point of cross-shape intersection of regional linear faults (see Fig. 2), the multiring structure with diameter of 150 to $300 \mathrm{~km}$ can be detected. This structure is independently detected according to the relief (including the satellite imagery: http://labmpg.sscc.ru/impact/ab1396.html) as well as according to the map of gravity anomalies (Fig. 6a). The multiring positive gravity anomaly (the nested ring system with common cen-
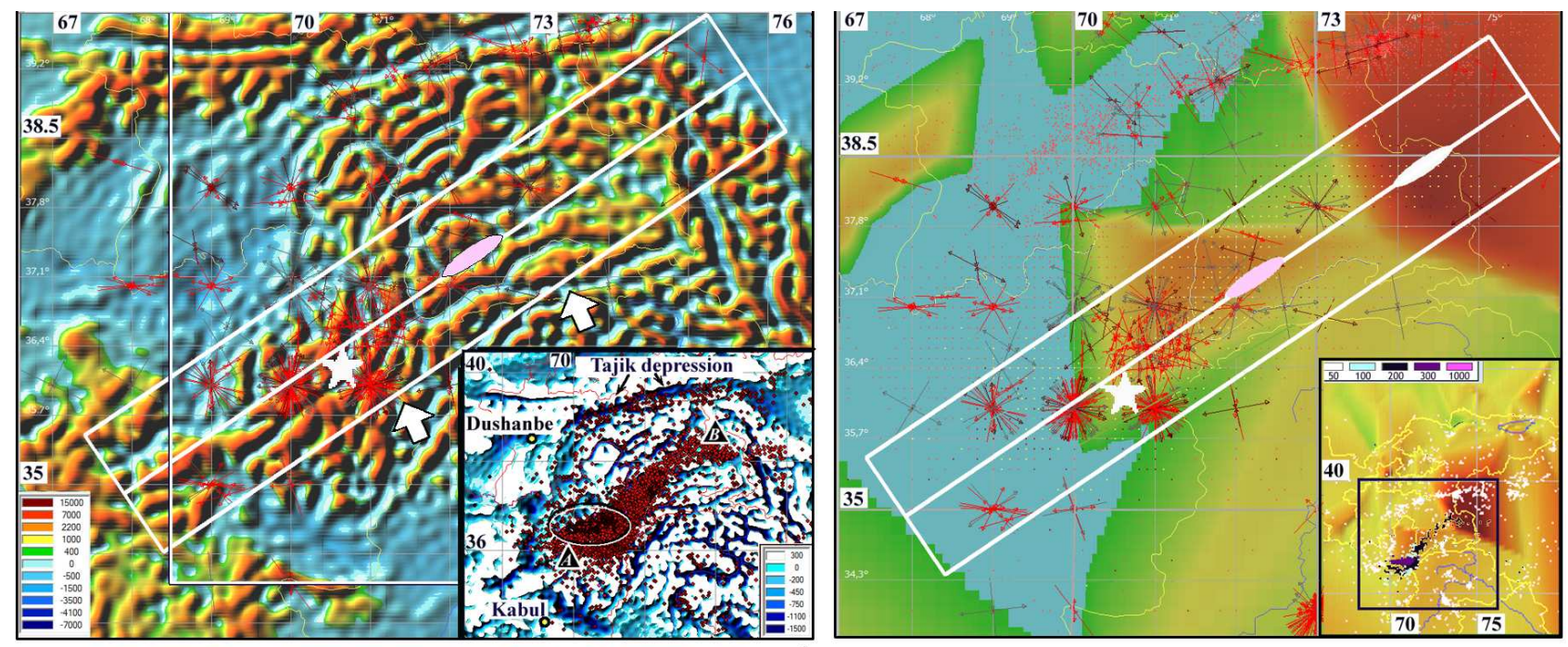

a.
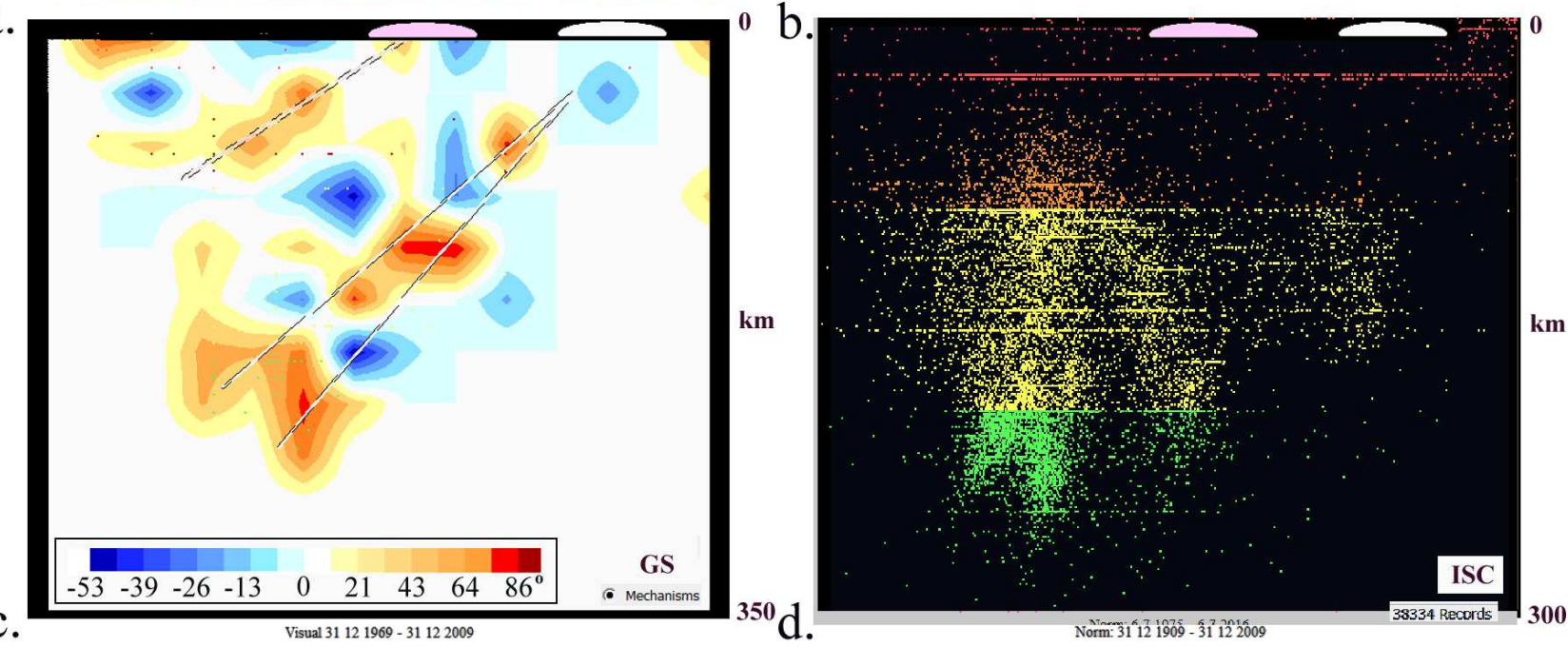

Figure 6 Structural elements of the PHKS zone based on the gravity, HF, and seismic catalogs data (ISC for 1905-2016, NEIC for 1973-2017, and GS RAS for 1993-2009): (a) the events epicenter mechanisms (catalog of GS RAS) and the cross-section profile on the background map of the multiring gravity anomaly (in MGal) distorted by the collision, in the inserted pictures: deep seismicity with $H \geqslant 50 \mathrm{~km}$ (NEIC) on the local component background of the gravity anomaly (the Andreev-Griffin transformation at $R=40 \mathrm{~km}$ ), a white oval or an asterisk marks the PHKS area of deep seismicity with $H \geqslant 200 \mathrm{~km}$; (b) the same on the background map of an HF; $(c)$ a cross section of the averaging mechanisms field (GS RAS); and ( $d$ ) a cross section of the seismicity (ISC). Colored white ovals show the locations of the gravity ring anomalies center and the HF anomalies maxima 
ter) above the PHKS zone is structurally similar to observations above the impact structures (for example, above the reliably established ones: "Vredefort," $D=140-250 \mathrm{~km}, 2.023 \mathrm{Ma}$; "Chicxulub," $D=180 \mathrm{~km}, 65.2 \mathrm{Ma}$; and "Manicouagan," $D=100 \mathrm{~km}, 210 \mathrm{Ma}$ ) [14]. However, the shape of the anomaly is more elongated and distorted by subsequent collisional processes (see Fig. 6a). The center of this anomaly is slightly offset to the NE from the epicenter of the deep seismicity cluster (the ellipse in the inserted pictures in Fig. $6 a$ ).

Second, the nearly radial (see Fig. 2) shape of seismic lineaments junction in the PHKS zone (in the plan) and $\lambda$-shaped configuration of the depth seismicity distribution (in the cross section) (see Fig. $6 d$ ) are similar to the pattern observed at the junction point of the four plates: the Philippine, the Pacific, the Okhotsk-sea, and the Eurasian, where the so-called "seismic nail" exists [15]. A similar $\lambda$-shape configuration of the depth distribution is observed in terms of weak seismicity and localized in the focal zone of the Klyuchevskoy volcanoes group [2].

Third, according to the GIS-ENDDB digital models of the HF, the increased anomalies in the thermal field (up to $276 \mathrm{~mW} / \mathrm{m}^{2}$ ) confined to the Pamir-Hindu Kush region are detected (see Fig. 6b), which enhances the similarity of this zone to the above-mentioned four plates junction in the area of the West Pacific subduction, where there is an anomaly $(D \sim 200 \mathrm{~km})$ up to $475 \mathrm{~mW} / \mathrm{m}^{2}$.

At the same time, the averaging parameters presented in Fig. 3 show a good coherence between contour configuration of $M_{\max }$ (constructed without taking into account the earthquakes of more "fragile" top layer of the Earth's crust) and the regional component of the HF field. Such a coherence may also indicate the relationship of depth seismicity averaged characteristics with the thermal field and can be indicative of controlling the depth seismicity from thermal processes in the upper mantle. The comparison of HF map with the PHKS zone seismicity shows the coincidence of this anomaly with the top of the deep seismic swarm extending from this point to the west-south-west direction, moving deep at an angle of $\sim 25^{\circ}$ to the horizontal (see Figs. $6 c$ and $6 d$ ).

These three patterns, as well as the manifestation of the material movement channel (of the same south-westerly trend in the plan) moving deep to 550-kilometer depth at the same angle $\left(\sim 25^{\circ}\right.$, see Fig. $\left.4 b\right)$, can suggest the presence in the Pamir-Hindu Kush zone (as in the other above-mentioned areas) of a seismically active sloping channel associated with a deep source of activity.

The spatial distribution of the most deep part mechanisms of seismic sources - in the PHKS zone (with $H \geqslant 100 \mathrm{~km}$ ) - shows here the upthrow mechanism preponderance which sharply distinguishes the character of the movements in this zone from the surrounding area. The "seismotectonic deformations of the near vertical uniaxial elongation" [16] predominance in the seismofocal zone suggests the presence of a deep channel of a material addition in the area. The activity of this material addition source can control the activation in the whole centeroriented seismolineament structure (possibly, being complicated by the collision processes) and can have various activities in different time periods. The GIS-ENDDB maps of "stretching" and "compressing" zones according to the summary data of the epicenters mechanisms can identify the dynamics of such tectonic activation.

\section{The averaging earthquake mechanisms field}

The "stretching" and "compressing" zones are the anomalies (Fig. 7) of the parameter Slip ${ }_{12}$, which is an average value of two Slip vectors along the first and the second nodal planes $\mathrm{np}_{1}$ and $\mathrm{np}_{2}$ from an earthquake focal-mechanism solution:

- the case: Slip $_{12}=30-90$ corresponds to a reverse-slip (upthrow) mechanism of compression; 


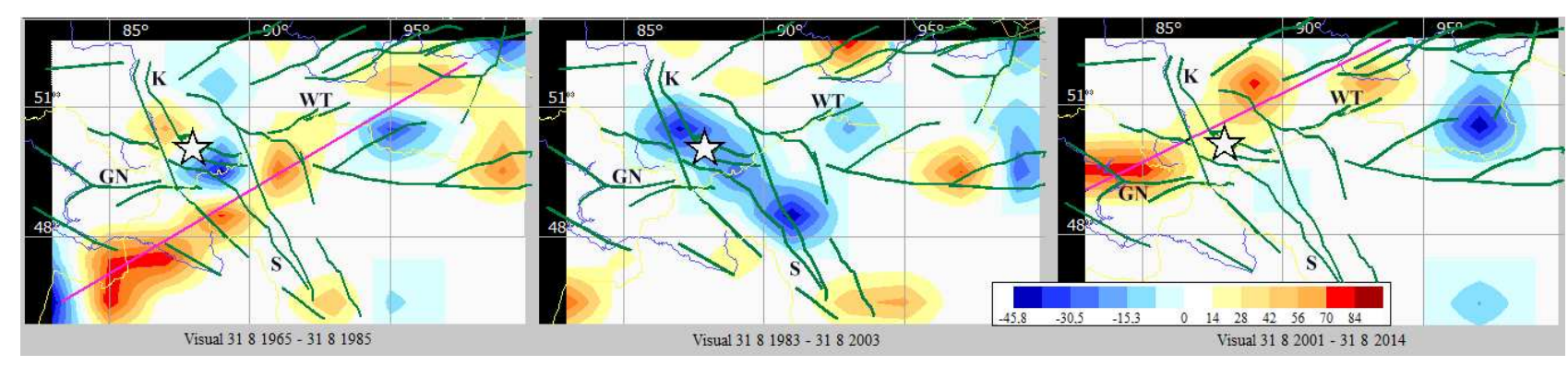

Figure 7 A map series of the averaging mechanisms field according to GS SB RAS catalog for 20-year sequential periods in the Altai-Sayan area: red color — "compressing" and blue color — "stretching" zones

- the case: Slip $_{12}=(-90)-(-30)$ corresponds to an extensional normal-slip mechanism (downthrows); and

- the case: Slip $_{12}=(-30)-30$ corresponds to a strike-slip (shift slide) mechanism.

The extension of a linear "compressing" zone to the east-north-east direction (in the period up to 1985) in the Altai-Sayan area repeats the direction of the $\mathrm{AB}$ seismolineament and corresponds to the direction of the Genghis-Narymsky (GN) and the West-Tannuola (WT) fractures (see Fig. $7 a$ ). Then, the dynamics of Slip ${ }_{12}$-distribution shows that this linear anomaly changes (in the period of 20 years before the Chui earthquake activity) by the "stretching" zone of the orthogonal direction along the Kurai $(\mathrm{K})$ and the Sagsay (S) fractures (see Fig. $7 b$ ). Beginning with the two-year period of the Chui event preparation (starting with 2001) and after it (up to now), the "compressing" zone is activating again having the same extension (to the east-north-east) but shifted to the north parallel to the location of the Chui event epicentral zone (see Fig. $7 c$ ). Such geodynamic regime restructuring possible variants was reflected in the occurrence of the above-mentioned short-term cluster along the $A B$-lineament eve of Chui event.

The area around the PHKS zone also demonstrates linear "compressing" zone presence to the east-north-east direction and local zones of the ring isometric positive anomaly of a "compressing" maximum. Although the "compressing" mechanism is usually associated with "upthrow," we associate this mechanism with the phenomenon of material addition and "swelling" of the lithosphere solid surface along center-oriented deep seismolineaments and in its active center.

Considering the latter and the fact that many characteristic features of the PHKS zone are found in other geodynamic areas: in the proven impact-magmatic structures, areas of volcanic activity, in subduction zones, one can speak about a seismotectonic control of all these areas activity by the deep mantle structures, namely, by a deep mantle focus and by the regional radial fracture system (the latter can be interpreted as derivatives of the focal source). In other words, we have identified the features (see also $[2,12,13]$ ) indicating the tectonic control of regional seismicity by both linear and point (ring) deep structures, i. e., by the long-living deep faults and by the focal depth source. The presence of the ring structure (in plan) marking a deep channel-shaped active source and of central-oriented system of deep faults may be interpreted, as one option, as signs of a possible permeant hypersonic impact of comet, generating in "fragile" top layer of the Earth's crust the structure of a "broken plate" (according to the hypotheses of "comet-galactic impacts" [17] and "shock-explosive tectonics" [18]). 


\section{Concluding Remarks}

The new data analysis methods and tools developed in the GIS-ENDDB system environment provide wider studies for enriching our knowledge about the structure and dynamics of the geological-geophysical environment based on geophysical evidences, the digital topographic and geophysical fields, as well as on geological data. For example, the results comparison of formalized calculation of seismolineaments with the maps of real geophysical manifestations and a more detailed study of the seismolineaments dynamics in anomalous geophysical zones allow the identification of objective characteristics of seismic and geodynamic regime of the territories. Such studies can help to put forward dynamic models of global tectonic processes and to give a wealth of prognostic information for seismologists (for example, about the earthquakes preparation, confined to the linear and ring tectonic structures), i.e., to solve fundamental and applied geodynamics problems. This has been demonstrated on the example of global seismolineament structures of seismicity passing through the PHKS zone and affecting on crust seismicity of Altay region. The presented examples are supported by newer methods included in the GIS-ENDDB complex research: the new GC algorithm for detecting linear structures, methods of $M_{\max }$-contours (maximum earthquake magnitudes), and of Slip 12 distribution (the averaging characteristic of earthquake source mechanism).

\section{References}

[1] Mikheeva, A. V., An. G. Marchuk, and P. G. Dyadkov. 2014. Geoinformation systems for studying seismicity and impact cratering using remote sensing data. Geographic information systems (GIS): Techniques, applications and technologies. Ed. D. Nielson. Engineering tools, techniques and tables ser. Nova Science Publishers. Ch. 7. 151-216. Available at: http://www .novapublishers . com/catalog/product_info.php?products_id=50334\&osCsid (accessed December 29, 2017).

[2] Mikheeva, A. V. 2016. Geostrukturnye elementy, vyyavlyaemye matematicheskimi algoritmami i tsifrovymi modelyami geoinformatsionno-vychislitel'noy sistemy GIS-ENDDB [Geostructural elements detected by mathematical algorithms and numerical models of the geoinformationcomputer system GIS-ENDDB]. Novosibirsk: Omega Print. 300 p. Available at: http:// elibrary.ru/item.asp?id=27622389 (accessed December 29, 2017).

[3] Gitis, V.G., and B. V. Ermakov. 2004. Osnovy prostranstvenno-vremennogo prognozirovaniya $\checkmark$ geoinformatike [Fundamentals of spatial-temporal forecasting in geoinformatics]. Moscow: FIZMATLIT. 256 p. Available at: http://www.rfbr.ru/rffi/ru/books/o_65375 (accessed December 29, 2017).

[4] Mikheeva, A. V., P. G. Dyadkov, An. G. Marchuk, and A. A. Egorov. 2016. Geoinformatsionnye tekhnologii ekspertnoy sistemy GIS-ENDDB ("Bazy dannykh prirodnykh katastrof Zemli") [Information technologies of the expert system GIS-ENDDB ("The Earth's Natural Disasters Databases")]. Vestnik NSU, Ser. Information Technologies 14(3):49-60. Available at: http: //jit.nsu.ru/article.php?11567+en_EN+10229 (accessed December 29, 2017).

[5] Vazhenin, A., A. Mikheeva, P. Dyadkov, and A. Marchuk. 2017. The software using digital databases and gis interface for detecting geodynamic structures. New trends in intelligent software methodologies, tools and techniques. Eds. H. Fujita, A. Selamat, and S. Omatu. Frontiers in artificial intelligence and applications ser. IOS Press. 297:576-592. doi: 10.3233/978-1-61499800-6-576.

[6] Schaeffer, A. J., and S. L. Lebedev. 2013. Global shear speed structure of the upper mantle and transition zone. Geophys. J. Int. 194:417-449. doi: 10.1093/gji/ggt095. 
[7] Dyadkov, P. G., and A. V. Mikheeva. 2010. The EEDB — Expert Earthquake Database for seismic-geodynamic research. Bull. NCC. Ser. Math. Model. Geophys. 13:15-30. Available at: http://bulletin.iis.nsk.su/article/803 (accessed December 29, 2017).

[8] Dyadkov, P.G., and A.V. Mikheeva. 2011. Metody vyyavleniya prostranstvennogo gruppirovaniya zemletryaseniy $\mathrm{v}$ seismogeodynamicheskom issledovanii rayonov Tsentral'noy Azii [Methods for detection of spatial clustering of earthquakes in seismogeodynamic study areas of Central Asia]. 15th Conference "Mathematical Methods of Pattern Recognition" Procceedings. Moscow: MAKS Press. 560-563.

[9] Nikolaev, N. I. 1988. Noveyshaya tektonika i geodynamika litosfery [The newest tectonics and geodynamics of the lithosphere]. Moscow: Nedra. 491 p. Available at: http://www.geokniga. org/bookfiles/geokniga-noveyshaya-tektonika-i-geodinamika-litosfery.pdf (accessed December 29, 2017).

[10] Oparin, V.N., and M. A. Guzev. 2008. Zonal'naya dezintegratsiya gornykh porod i ustoichivost' podzemnykh vyrabotok [The zonal disintegration of rocks and stability of underground workings]. Novosibirsk: SB RAS Publs. 278 p. Available at: http://elibrary.ru/item.asp?id=19602004 (accessed December 29, 2017).

[11] Ustyantsev, V. N. 2013. O edinom mekhanizme structuroobrazovaniya sistemy Zemli [On a single mechanism of structure formation of the Earth system]. LAP LAMBERT Academic Publishing. $620 \mathrm{p}$.

[12] Kalinnikov, I. I., and A. V. Mikheeva. 2016. Algorithms of building lineaments in the program GIS-ENDDB. Bull. NCC. Ser. Math. Model. Geophys. 19:1-9. Available at: http://bulletin . iis.nsk.su/article/1563 (accessed December 29, 2017).

[13] Mikheeva, A. V., and An. G. Marchuk. 2016. Geographical information system "The Earth's natural disasters Database" (ENDDB) as a tool for studying complex geotectonic structures. Bull. NCC. Ser. Comput. Sci. 39:25-36. Available at: http://bulletin.iis.nsk.su/article/1556 (accessed December 29, 2017).

[14] Mikheeva, A. V. 2008. The new data of "Catalogue of the Earth's impact structures". Geochim. Cosmochim. Ac. 72(12, Suppl. 1):A627. doi: 10.1016/j.gca.2008.05.016.

[15] Vadkovsky, V.N. 2012. Subvertikal'nye skopleniya gipotsentrov zemletryaseniy — seysmicheskie "gvozdi" [Subvertical accumulation of earthquake hypocenters — seismic "nails"]. Vestnik ONZ RAS 4:NZ1001. Available at: http://onznews.wdcb.ru/publications/v04/2012NZ000110/ 2012NZ000110.pdf (accessed December 29, 2017).

[16] Shevchenko, V.I., I. P. Dobrovolsky, and A. A. Lukk. 2010. Deformatsii odnoosnogo udlineniya i anomal'nye mekhanizmy ochagov zemletryaseniy v zemnoy kore Tadzhikskoy depressii [Seismotectonic deformation of the uniaxial elongation and anomalous mechanisms of earthquakes in the Earth's crust of Tajik depression]. Geofizicheskiye issledovaniya [Geoph. Res.] 11(1):15-26. Available at: http://elibrary.ru/item.asp?id=13860879 (accessed December 29, 2017).

[17] Barenbaum, A.A. 2009. Galaktotsentricheskaya paradigma i ee sledstviya [Galactocentric paradigm in geology and astronomy]. Moscow: LIBROKOM. $547 \mathrm{p}$.

[18] Zeilik, B.S. 1991. Udarno-vzryvnaya tektonika i kratkiy ocherk tektoniki plit [Shock-explosive tectonics and a plate tectonic synopsis]. Alma-Ata: Gylym. 120 p.

Received February 20, 2017 


\title{
Алгоритмы и методы геоинформационно-экспертного анализа данных в ГИС ENDDB*
}

\author{
А. В. Михеева ${ }^{1}$ И. И. Калинников ${ }^{2}$ \\ anna@omzg.sscc.ru
}

${ }^{1}$ Институт вычислительной математики и математической геофизики СО РАН, Россия, г. Новосибирск, пр. акад. Лаврентьева, 6

${ }^{2}$ Институт физики Земли им. О. Ю. Шмидта РАН, Россия, г. Москва, ул. Б. Грузинская, 10/1

Геоинформационная программная система изучения природных катастроф Земли GISENDDB ориентирована на изучение причинно-следственных связей катастрофических событий в истории нашей планеты. Она содержит данные о сейсмической активности планеты, тепловом потоке, детальном рельефе, аномалиях гравитационного поля и распределении космогенных структур Земли. Постоянно развиваются методы анализа этих данных. В числе последних обновлений в подсистемах информационного и математического обеспечения GIS-ENDDB: алгоритм построения глобальных линеаментов сейсмичности по большим кругам Земли; расчет изолиний максимальных магнитуд землетрясений и осредненного механизма землетрясений на единицу площади; функции визуализации и трансформации геофизических полей, функции распределения в разрезе различных характеристик сейсмичности и данных томографии. Все это помогает расширить классические методы геотектонического исследования комплексным научно-экспериментальным подходом, позволяющим выделять современные тектонически активные границы и разломы, изучать пространственную взаимосвязь сейсмичности и космогенных палеоструктур (связанных с историческим прошлым Земли) и, в конечном итоге, интерпретировать данные с точки зрения построения сейсмогеодинамических моделей литосферы.

Ключевые слова: каталог импактных структур; каталоги землетрясений; геотектонические морфоструктурные элементы; геофизические аномалии; экспертно-геоинформачионный подход

DOI: $10.21469 / 22233792.3 .1 .03$

\section{Литература}

[1] Mikheeva A. V., Marchuk An. G., Dyadkov P. G. Geoinformation systems for studying seismicity and impact cratering using remote sensing data // Geographic information systems (GIS): Techniques, applications and technologies / Ed. D. Nielson. - Engineering tools, techniques and tables ser. - Nova Science Publishers, 2014. Ch. 7. P. 151-216. http://www. novapublishers. com/catalog/product_info.php?products_id=50334\&osCsid.

[2] Михеева A.В. Геоструктурные элементы, выявляемые математическими алгоритмами и цифровыми моделями геоинформационно-вычислительной системы GIS-ENDDB. - Hовосибирск: Омега Принт, 2016. 300 c. http://elibrary.ru/item.asp?id=27622389.

[3] Гитис В. Г., Ермаков Б. В. Основы пространственно-временного прогнозирования в геоинформатике. - М.: Физматлит, 2004. 256 c. http://www.rfbr.ru/rffi/ru/books/o_65375.

[4] Михеева А.В., Дядъков П. Г., Марчук Ан. Г., Егоров А.А. Геоинформационные технологии экспертной системы GIS-ENDDB («Базы данных природных катастроф Земли») // Вестн. НГУ. Сер. Информационные технологии, 2016. Т. 14. №3. С. 49-60. http://jit.nsu.ru/ article.php?11567+en_EN+10229.

*Работа выполнена при финансовой поддержке РФФИ, проект №17-05-01234. 
[5] Vazhenin A., Mikheeva A., Dyadkov P., Marchuk A. The software using digital databases and gis interface for detecting geodynamic structures // New trends in intelligent software methodologies, tools and techniques / Eds. H. Fujita, A. Selamat, S. Omatu. - Frontiers in artificial intelligence and applications ser. - IOS Press, 2017. Vol. 297. P. 576-592. doi: 10.3233/978-1-61499-800-6-576.

[6] Schaeffer A.J., Lebedev S.L. Global shear speed structure of the upper mantle and transition zone // Geophys. J. Int., 2013. Vol. 194. P. 417-449. doi: 10.1093/gji/ggt095.

[7] Dyadkov P. G., Mikheeva A. V. The EEDB - Expert Earthquake Database for seismic-geodynamic research // Bull. NCC. Ser. Math. Model. Geophys., 2010. Vol. 13. P. 15-30. http://bulletin. iis.nsk.su/article/803.

[8] Дядъков П. Г., Михеева А.В. Методы выявления пространственного группирования землетрясений в сейсмогеодинамическом исследовании районов Центральной Азии // Математические методы распознавания образов: 15-я Всеросс. конф. - М: MAKC Пресс, 2011. С. 560563.

[9] Николаев Н. И. Новейшая тектоника и геодинамика литосферы. - М.: Недра, 1988. 491 с. http://www.geokniga.org/bookfiles/geokniga-noveyshaya-tektonika-i-geodinamikalitosfery.pdf.

[10] Опарин B. Н., Гузев M. А. Зональная дезинтеграция горных пород и устойчивость подземных выработок. - Новосибирск: Изд-во СО РАН, 2008. 278 c. http://elibrary.ru/item.asp?id= 19602004.

[11] Устъянцев В.H. О едином механизме структурообразования системы Земля. LAP LAMBERT Academic Publishing, 2013. 620 c.

[12] Kalinnikov I. I., Mikheeva A. V. Algorithms of building lineaments in the program GIS-ENDDB // Bull. NCC. Ser. Math. Model. Geophys., 2016. Vol. 19. P. 1-9. http://bulletin.iis.nsk.su/ article/1563.

[13] Mikheeva A. V., Marchuk An. G. Geographical information system "The Earth's natural disasters Database" (ENDDB) as a tool for studying complex geotectonic structures // Bull. NCC. Ser. Comp. Sci., 2016. Vol. 39. P. 25-36. http://bulletin.iis.nsk.su/article/1556.

[14] Mikheeva A. V. The new data of "Catalogue of the Earth's impact structures" // Geochim. Cosmochim. Ac., 2008. Vol. 72. No. 12. Suppl. 1. P. A627. doi: 10.1016/j.gca.2008.05.016.

[15] Ваджовский В.Н. Субвертикальные скопления гипоцентров землетрясений - сейсмические «гвозди»// Вестн. ОНЗ РАН, 2012. № 4. C. NZ1001. http://onznews.wdcb.ru/publications/ v04/2012NZ000110/2012NZ000110.pdf.

[16] Шевченко В. И., Добровольский И. П., Лукк А. А. Деформация одноосного удлинения и аномальные механизмы очагов землетрясений в земной коре Таджикской депрессии // Геофизические исследования, 2010. Т. 11. № 1. С. 15-26. http://elibrary.ru/item. asp?id=13860879.

[17] Баренбаум A. А. Галактоцентрическая парадигма в геологии и астрономии. - М.: ЛИБКОPOM, 2009. 547 c.

[18] Зейлик Б. С. Ударно-взрывная тектоника и краткий очерк тектоники плит. - Алма-Ата: Гылым, 1991. 120 с. 